\title{
Effect of Fasting and Foliar Application with Urea on Egyptian Lime Trees Productivity B. Vegetative growth, leaf chlorophyll content, leaf carbohydrate fractions and fruit quality in lime trees
}

\author{
EL-Tanany M.M. and Mervate S.M.Sourour and Enas A. Tayel ${ }^{1}$
}

\begin{abstract}
This investigation was carried out during 2005/2006 and 2006/2007 growing seasons to study the effect of holding irrigation periods and foliar application with urea on vegetative growth, leaf chlorophyll content, leaf carbohydrate fractions and fruit quality of lime trees. The treatments were; holding irrigation for $15,30,45$ and 60 days with three urea spraying treatments; once, twice and without spray.

The obtained results indicated that, holding irrigation for 30 days with spraying once or twice, in both seasons, gave the best intereaction for increasing shoot length and leaf area. As for leaf chlorophyll and carbohydrate concentrations, the results revealed that, holding irrigation for either 30 or 45 days with urea spraying twice, in both seasons, markedly increased leaf chlorophyll catogeries (A\&B) and carbohydrate fractions concentrations and gave the best interactions. Moreover, holding irrigation for 15 days without foliar urea, in both seasons, gave the highest interaction for leaf starch and total carbohydrates when compared with holding irrigation period for 60 days with urea spraying twice. For physical fruit properties; including fruit length and diameter; the results proved that, in the first season, holding irrigation for either 15 or 45 days with urea application; once, twice or without foliar urea (as a control) markedly increased fruit length and diameter and gave the best interactions. However, in the second season, the differences were not significant in this respect. Fruit juice volume, in both seasons, significantly increased when irrigation was held for 15 days. Besides, no effect of foliar urea spraying treatments in this respect; especially, in the first season. Moreover, the best interactions for lime juice volume were obtained between holding irrigation for 15 days with urea spraying once. For chemical fruit properties, including total soluble solids, fruit juice acidity and vitamin $\mathrm{C}$ percentages; by holding irrigation for either 30 or 45 days and urea application twice, in both seasons, caused significant increase in their fruit juice content of these tested variables and gave the best interactions. On the contrary, holding irrigation for 60 days with or without foliar urea sprays had a negative effect on all the above mentioned parameters and reduced fruit quality.
\end{abstract}

\section{INTRODUCTION}

Citrus trees require for accepted growth an irrigation regime that meet the real requirements of trees. In other words, trees must be grown under optimum level of irrigation water to obtain a better growth (Abd ELMessih et al (1977); Dariusz (1986)and Swellem (1986). On the other hand, minimizing or maximizing this level causes a negative effect in this respect (Levy et al. 1978). Unfortunately, the Egyptian lime trees growers are accustomed to supply trees with excess water which creates different problems to both soil and cultivated citrus trees. In this respect, water is the most important factor in citrus orchards, especially in areas of limited water resources. Schedule irrigation is the main factor in improving irrigation, the trees productivity and water use efficiencies. In addition, water deficit stress has been shown to affect many plant physiological processes, for example, plant water potential (McCutchan and Shackel, 1992), plant growth (Acevedo et al., 1971), CO2 assimilation and sugar accumulation, (Robinson et al., 1988 and handa et al.,1983) and plant productivity (Bradford and Hsias, 1982). Thus, one of the best approaches to achieve good water management program is estimating the suitable citrus tree water requirements. Previous studies of deficit irrigation on citrus trees have reported reductions in plant water status, gas exchange activity, decreases in vegetative growth and yield, and change in fruit quality depending on the severity of the water stress and on the phenological stage of vegetative and reproductive growth when deficit irrigation was applied (GonzalzAltozano and Castel 2000 and Romero et al., (2006). Besides, minimizing water irrigation during the lime fasting duration lead to increase leaf ammonium content; also foliar application with urea during July and August can be increases the ammonia accumulation over the accumulating due to hold irrigation periods. Undoubtly, raising leaf ammonium content at right time, prior to / or during floral induction and differentiation might influence physiological processes, growth, yielding capability and fruit quality of lime trees. Direct dosage of nitrogen by the leaves can be effective in reducing the dose needed by the trees; also, reduced nitrogen contamination of ground water (Ali \& Lovatt 1992). Because the fasting trees yield was very little; therefore, by holding irrigation periods and foliar application with

${ }^{\mathbf{1}}$ Horticulture Research Institute, A.R.C., Egypt.

Received June 23, 2011, Accepted June 29, 2011 
urea in late summer could increase lime fruit yield and improvement quality with high price and achieved highly economic income.

Consequently, the present study was designed to test the effect of holding irrigation periods and foliar sprays with urea on vegetative growth, leaf chlorophyll content, carbohydrate fractions and fruit quality of lime trees.

\section{MATERIALS AND METHODS}

The present study was carried out in a private orchard located at Ganabha village, Housh Essa center, Behera governorate, Egypt during the 2005/2006 and 2006/2007 growing seasons. The objective of the study was to evaluate the influences of holding irrigation periods and foliar application with urea on vegetative growth (shoot length and leaf area), leaf chlorophyll categories, carbohydrate fractions and fruit quality of Balady lime trees (citrus aurantifolia, linus).

Mature thirty six trees ( 8 years old) of Balady lime trees budded on sour orange (Citrus aurantium,L.) rootstock were used in this study, the selected trees were nearly uniform in vigor and size, grown in clay loam soil (silt soil) and spaced at $5 \mathrm{~m}$. apart. The trees were irrigated with Nile water using surface irrigation system every 12 days during the growing seasons; from February to May.

The experimental trees were divided into four groups with nine trees for eachgroup and the main treatments were as follows:

1)First group; holding irrigation for 15 days (asa control treatment).

2) Second group; holding irrigation for 30 days.

3) Third group; holding irrigation for 45 days.

4) Fourth group; holding irrigation for 60 days; within each group; three trees sprayed with urea solution only once (on July, 5), as well as, other three treas sprayed with urea twice (on July, 5 plus August, 5), while three trees were left without spray as control treatment. Each spray treatment was achieved by spraying the foliage of the trees until drip point of the solution using a 20 litres hand sprayer. Each tree received 6.5 liters from the spray solution; i.e $65 \mathrm{gm}$ urea per tree every spray using commercial urea with low-biuret $(46.5 \mathrm{~N} \%)$. Guard rows were left around the trees of each spray treatment. Different treatments were repeated on the same trees for the two successive seasons. The following measurements were:

\section{Vegetative characteristics}

\section{A. Shoot length and leaf area estimation:}

In October of 2005 and 2006 seasons, the average length of 5 randomly selected vegetative shoots on each tree was recorded. In addition, 5 fully expanded mature leaves were taken at random from each replicate and the leaf area was calculated by a Planimeter.

\section{B. Chlorophyll fractions $(A \& B)$ determination:}

The forementioned leaf samples taken for estimating leaf area, also, used for different chlorophyll catogeries determination in $0.1 \mathrm{gm}$ of meserating fresh leaf sample using N,N- dimethyl formamide method as described by Moran and Porath (1980).

\section{Carohydrate fractions determination:}

The leaf samples used for ammonium determination which mentioned in details in part 1 of study, also, were used for carbohydrate fractions determination (Reducing, total soluble sugars and starch); only in leaf samples collected after 30 days from urea application; $0.3 \mathrm{gm}$ of the ground dried leaves of each sample was used for extraction three times by hot distilled water according to A.O.A.C (1985). The reducing sugars in this extract were determined by Nelson arsenomolybdate method (Malik and Singh,(1980). The total soluble sugars were determined using phenol-sulphuric acid method according to Dubois et al (1956). The starch was estimated in $0.1 \mathrm{gm}$. of the residue after water extraction in terms of glucose, using Nelson's method as described by Malik and Singh (1980).

\section{Fruit quality determination:}

At harvest time (on June,20) of both seasons, 7 fruits were taken at random from each tree for different fruit characters measurements. In each fruit sample, fruit length, diameter and fruit juice volume were recorded. Total soluble solids content (TSS) in fruit juice was determined by hand refractometer. Acidity, as citric acid percent, was also determined using $0.1 \mathrm{~N}$ sodium hydroxide. Vitamin $\mathrm{C}$ content in the juice was determined by titration with 2.6 dichlorophenol endophenol dye (A.O.A.C 1985).

All data were subjected to statistical analysis by the technique of analysis of variance in split plot design according to the method described by Snedecor and Cochran (1982).

\section{RESULTS AND DISCUSSION}

Effect of holding irrigation periods and foliar application with urea on shoot length and leaf area:

Data presented in Table (1) indicated that, holding irrigation for 30 days, in both seasons, as well as for 45 days, in the second one, had a significant effect on the average shoot length of the treated trees. On the other hand, holding irrigation for 60 days, in both seasons, gave the lowest values shoot length with non significant differences.

Concerning the effect of foliar sprays with urea on shoot length, the data in Table (1) revealed that lime 
trees sprayed with urea either once or twice, gave the highest shoot length when compared with the control (without urea) and the differences were significant.

The interaction between holding irrigation period for 30 days and spraying once or twice with urea, in both seasons, gave the highest shoot length compared with the other interactions. with significant differences. On the other hand, the shortest shoots were obtained when irrigation was held for 60 or 45 days with or without spraying with urea, as shown in Table (2). These results were greatly confirmed by those previously recorded by Hilgeman (1977) who reported that water stress affected vegetative growth sooner than it affected fruit yield or size. Moderate stress (1350 mm. $\left.\mathrm{yr}^{-1}\right)$ reduced conopy growth and trunk enlargement but did not affect average yield or final fruit size. As well as, Levy et al(1978) and Goell et al (1981) found that the main effect of water stress on 'Marsh' grapefruit trees was to limit canopy development. However, excessive growth was induced by intensive irrigation and fertilization. Similarly, Hilgeman and Sharp (1970), using Valencia orange trees, reported that growth measurements were positively correlated with the increase of soil moisture. EL-Boray et al., (1995) using Washington Navel orange trees, reported that excess of water irrigation levels was the superiour for increasing vegetative growth; it gave the highest shoot length and canopy volume per tree. However, the deficit of water irrigation levels gave the worst effect in this respect. Romero et al., (2006) using Clemenules mandarin; found that deficit irrigation treatment reduced canopy volume, relative growth rate the decreases in vegetative growth and yield depended on the severity of the water stress. The effect of nitrogen rate and application number on increasing shoot length was reported by EL-Boray et al., (1995).

The data in Table (1) showed that, in both seasons, the highest leaf area was obtained by holding irrigation treatments for either 15 or 30 days. On the other hand, the lowest average leaf area was obtained by holding irrigation period for 60 days and the differences were statistically significant.

Regarding foliar application with urea, the data in the same Table revealed that lime trees sprayed with urea once or twice, in both seasons, gave significantly higher average leaf area than the control (without foliar urea) and the difference was significant.

Concerning the intereactions among holding irrigation periods with foliar sprays with urea; the data in Table (2), generally indicated that, holding irrigation periods for either 15 or 30 days with urea spraying twice ; in both seasons; gave the largest leaf area, and gave the best interactions. Likewise, in the second season, the interaction between holding irrigation for 15 or 30 days with single urea spray gave the same above mentioned trend, i.e gave the best interactions in this respect. However, the lowest interaction was obtained by holding irrigation for 60 days single, double or without urea spray treatments, (Table 2). These results are in agreement with those reported by EL-Boray et al., (1995), Abd EL-Messih et al,(1977) using Washington Navel orange trees. They reported that deficit irrigation reduced canopy width, leaf size, tree height and trunk diameter.

An increment of leaf area by foliar urea application and with increasing the rate and number of nitrogen application was reported by EL-Boray et al., (1995), Hassan et al., (2001) and Tomes \& Robert (1993) using citrus trees.

Effect of holding irrigation periods and foliar application with urea on leaf chlorophyll fractions:

\section{A. Chlorophyll A content :}

The exhibited results in Table (3) asserted that holding irrigation treatment for 45 days, in both seasons, significantly increased leaf chlorophyll A content than other treatments. However, the lowest value for chlorophyll A content was obtained from holding irrigation for 60 days and the difference was significant.

As for the effect of foliar sprays with urea on chlorophyll A content; it was noticed that twice urea sprays, in both seasons, raised significantly chlorophyll A content compared with the control treatment (without foliar urea) and the differences were significant, Table (3).

Regarding the interaction among holding irrigation periods and urea foliar sprays; on chlorophyll A content are presented in Table (4). The results indicated that holding irrigation for 45 days with twice urea sprays, in both seasons, significantly increased leaf chlorophyll A content. On the contrary, in most cases, holding irrigation for 60 days with or without spraying with urea, in both seasons, significantly decreased leaf chlorophyll A content.

\section{B. Chlorophyll B content}

Concerning the effect of holding irrigation periods on leaf chlorophyll B content, the results in Table(3), generally, indicated that holding irrigation periods for 15,30 and 45 days caused an increase in leaf chlorophyll B content compared with holding irrigation for 60 days and the differences were significant. These results were valid during both experimental seasons.

A for the effects of foliar sprays with urea on leaf chlorophyll $\mathrm{B}$ concentrations, the data in Table(3) showed that, in the first season, there was no significant effect of urea sprays on leaf chlorophyll B content. In the second season, urea sprays twice had significantly higher leaf chlorophyll B content than either single spray or the control (no urea spray) and the differences were significant. 
Concerning the interaction among holding irrigation treatments and urea sprays, the results in Table (4) showed that holding irrigation period for 45 days with twice urea spraying treatment, in both seasons, was significantly superiour in leaf chlorophyll B than other interactions. On the other hand, holing irrigation for 60 days irrespective whether it was sprayed with urea; once, twice or without urea sprays, as well as, holding irrigation for 45 days without urea spray, gave the same trend in this respect, (Table 4).

\section{Leaf total chlorophyll $(A+B)$ :}

The results of the first season showed a slight increase in leaf total chlorophyll content of all different holding irrigation treatments when compared with that of holding irrigation period for 60 days, but the differences were not high enough to be significant, Table (3). However, the data in the second season, clearly exerted that holding irrigation period for 45 days increased significantly total leaf chlorophyll content, when compared with holding irrigation for 60 days which gave the lowest values for total leaf chlorophyll.

As for the effect of foliar sprays with urea solution on total chlorophyll content, the results in table (3) revealed that lime trees sprayed with urea; twice, in the second season,. increased significantly of total chlorophyll comparing with those of sprayed once or without urea spray as a control. However, in the first season, the differences were not big enough to be significant.

Concerning the interaction effect among holding irrigation periods and foliar application with urea on total leaf chlorophyll content, the results in Table 4 indicated that, in the first season, the interactions between holding irrigation periods and urea spraying treatments were not significant in this respect. However, in the second season, holding irrigation for 45 days with twice sprays, gave the best interaction in increasing total leaf chlorophyll content and the differences were significant, The obtained results were in line with those reported by Abdel- Nasser and El-Shazly (2000) using apple trees. They revealed that there was a marked decrease in leaf chlorophyll content as a result of soil moisture tensions at 50 and $70-\mathrm{cb}$, and they attributed such a reduction to the role of water as a substrate for all vital processes in plant tissue epecially in chlorophyll formation. Ahmed (1990) and Johnson et al (1982). using fig plants, reported that under severe water stress ; the leaf chlorophyll A and B content was decreased.. They added that the reduction in leaf chlorophyll was associated with water stress.

Effect of holding irrigation periods and foliar application with urea on leaf carbohydrate fractions:

The data concerning the influence of holding irrigation periods on leaf reducing, non-reducing and total soluble sugars contents as shown in Table (5), generally revealed that holding irrigation periods for 30 days and followed by 45 days, in both seasons, significantly increased leaf reducing sugar, non-reducing and total soluble sugar contents. However, holding irrigation treatments for 15 days or 60 days significantly reduced of these tested variables, Table(5).

Results of leaf starch content showed that holding irrigation for 15 or 45 days, in the second season, raised significantly starch percentage, while in the first season, the differences were not significant between three holding irrigation periods in this respect, On the contrary, holding irrigation for 60 days, in both seasons, gave the lowest percentage of leaf starch and the differences were significant.

For total leaf carbohydrates percentages; results, in both seasons, were similar to that found in leaf reducing sugar, non- reducing and total soluble sugar percentages; i.e with holding irrigation for 30 and 45 days significant increase of leaf total carbohydrate content was observed. On the other hand, holding irrigation for 60 days gave the lowest values, Table (5).

The data concerning the effect of foliar application with urea on leaf carbohydrate fractions are presented in table (5) indicated that, urea spraying t twice raised significantly all carbohydrate fractions in the leaves compared with those of sprayed once or without urea spray and the differences were significant, (Table5). In the same time, results of leaf starch content indicated that no significant effect of urea sprays on this tested variable, especially in the first season.

The interactions among holding irrigation periods and foliar application with urea presented in Table (6), generally revealed that, in both seasons, holding irrigation for 15,30 and 45 days with urea spraying twice gave the best interactions for reducing, non-reducing sugars and total sugars content but the differences were not high enough to be significant. Results of leaf starch and carbohydrates; showed almost similar trend as formentioned before, i.e no significant interaction was noticed for these two parameters, except that interaction between holding irrigation for 30 days with out foliar urea which gave the highest interations compared with the interation between holding irrigation period for 60 days with urea spraying twice which gave the worst interaction,(Table6). These results agree with many investigators such as Ginestar and Castel (1996), Gonzalez-Altozano and Castel (1999) and Romero et al., (2006), using Clementine citrus trees. Mareover, Jonson et al., (1982) and Ahmed (1990) using Ficus benjamaina and fig transplants, respectively, they found that carbohydrate accumulation reduction was associated with water stress. Under severe water stress total carbohydrates were decreased. 
Concerning the effect of foliar application with urea on leaf carbohydrate fractions; Doring and ludders (1981) reported that with increasing the rates of ammonium and urea application to calamodine trees (Citrus madurensis) a corresponding increase in leaf carbohydrates was noticed. Romero-Aranda and Syvertsen (1996) using Valencia orange and Duncan grapefruit trees, reported that leaf total carbohydrate content increased with increasing the number of foliar urea sprays.

Effect of holding irrigation periods and foliar application with urea on physical fruit properties:

Fruit length and diameter results as shown in Table 7 differed significantly from one season to another; in the second season, the differences were not high enough to be significant, while in the first one, holding irrigation for 15 or 45 days caused significant increases in length and diameter of lime fruits, when compared with other treatments (Table 7).

As for fruit juice volume, the results in Table 7 indicated that, in both seasons, holding irrigation for 15 days gave significantly higher juice volume than that of the other treatments. On the other hand, holding irrigation for 60 days gave the lowest fruit juice volume.

Concerning the effect of foliar application with urea on fruit length, diameter and juice volume, the results in Table 7 revealed that different foliar spraying treatments did not affect on these parameters in both seasons, except in the second one, where sprayed lime trees once gave the highest juice volume compared with other treatments including the control (without urea spray).

Data concerning the interation among holding irrigation treatments with foliar application with urea presented in Table 8 revealed that holding irrigation for 15 or 45 with urea spraying once, twice or control gave the best interactions in the fruit length and diameter during the first season of the study. On the contrary, in the second season, the interactions were not significant (Table 8). For fruit juice volume, the interaction between holding irrigation for 15days with urea spraying once or twice was superiour in fruit juice volume. On the other hand, the lowest interactions was obtained from holding irrigation for 60 days with or without foliar urea application. This was valid for fruit length, diameter and juice volume, (Table8). These results agreed with those reported by levy et al (1979), using Marsh grapefruit; they found that shortening the interval between irrigation from 40 to 21 days increased Marsh grapefruit size. On the other hand, many investigators such as Castel and Buj (1990), Levy et al(1978) and Heller et al., (1973) reported that water deficits in citrus usually result in smaller harvest fruit size. In opposite side, Hilgeman and Sharp (1970), using lemon trees, suggested that periods of deficit irrigation followed by a return to full irrigation would not necessarily result in smaller harvest fruit size.

The reduction in juice percent and increased peel thickness of March grapefruit by extending the interval between irrigation was reported by Bredell and Barander (1977). In opposite direction, Levy et al., (1979) stated that increased plant water stress during summer did not affect the physical characteristics of March grapefruit, although it affected the internal quality. The effect of foliar application with urea on increasing of fruit length and diameter of Balady mandarin trees was reported by Ahmed and AboShelbya (1988) and El-Boray et al., (1995).

Concerning the fruit juice volume, Ahmed and AboShelbaya (1988), using Balady mandarin trees, found that fruit juice percent was increased by all urea and micronutrients treatments. Similarly, EL-Boray et al., (1995) using Washington navel orange, found that juice volume of fruits recorded an increase with increasing irrigation water level. They added that the effect of nitrogen application on juice volume revealed an opposite trend. On the other hand, Saleem et al., (2008) reported that no effect of foliar sprays with low-biuret urea on juice content of sweet orange fruits was observed.

Effect of holding irrigation periods and foliar application with urea on chemical fruit properties:

The effect of holding irrigation periods on the total soluble solids (T.S.S), acidity and vitamin C contents are represented in Table 9.The data indicated that, in both seasons, holding irrigation for 30 or 45 days gave significantly higher values than the other treatments in this respect, except that in the first season, where holding irrigation treatments for 15,30 and 45 days gave the highest values of vitamin $\mathrm{C}$ content compared with that of holding irrigation for 60 days, (Table 9).

As for the effect of foliar application with urea on total soluble solids, acidity percentages and vitamin C contents, the results in Table 9 revealed that, in both seasons; twice urea spraying treatment during July and August, increased significantly these parameters compared with those of sprayed once or without urea spray which gave the lowest values in juice acidity, soluble solids and vitamin C contents, Table(9).

The results of interactions among holding irrigation periods and foliar spraying with urea, represented in Table 10 and showed that, in both seasons, holding irrigation for 45 days with urea spraying twice gave the best interation in juice Vitamin C content compared with the other interations.

As for the interation of acidity, results in Table (10) indicated that in the frist season, holding irrigation for 30 or 45 days with urea spraying twice was superiour while in the second season, holding irrigation for 45 
days with urea spraying once or twice gave the highest interaction compared with other interations.

As for total soluble solids percentage interaction, results in Table (10) showed that, the same trend as that of acidity percentage, especially in the first season of study while, in the seconds one, holding irrigation for 30 days with urea spraying twice, gave the highest interaction and the differences were significant. On the other hand, the worst interactions in chemical fruit properties were obtained when irrigation was held for 60days (Table10). These results were in line with those reported by EL-Boray et al.,(1995) working on Washington Navel orange trees, who found that T.S.S/acid ratio was increased as the irrigation level increased. On the other hand, Young and Garnsey (1977), Levy et al, (1978a,1979) and Cruse et al(1982) reported that drought increase citrus juice acidity. In addition, Wiegand and Swanson (1982) using Marsh grapefruit, reported that summer water stress on acid accumulation was relieved and was pronounced than the effect of stress on T.S.S.

Increasing fruit juice acidity, vitamin $\mathrm{C}$ content and T.S.S due to foliar application with urea and due to double of urea sprays was reported by Albrigo (1999) using Valencia orange trees, Ahmed and Abo-Shlebaya (1988) using Balady mandarin trees, and EL-Tanany and Abdel Messih (2009), using Valencia orange trees.

\section{CONCLUSION}

From the results of the present study, it can be concluded that holding irrigation for either 30 or 45 days with urea spaying twice gave the highest shoot length, leaf area, leaf chlorophyll categories (A\&B) and leaf different carbohydrate fractions and gave the best interaction, except leaf starch content which differed from one year to another. Besides, these treatments improved internal fruit quality including total soluble solids \%, Acidity $\%$ and vitamin $\mathrm{C}$ content. However, physical properties including fruit length and diameter markedly increased only in the first season, while fruit juice volume markedly increased when irrigation was held for 15 Days with foliar applications once or twice with urea and resulted in the best interactions. On the other hand, holding irrigation for 60 days with or without foliar urea sprays had a negative effect on the above mentioned parameters and reduced fruit quality.

\section{RE FERENCES}

Abd El-Messih, M.N.; A. EL-Nokrashy and ELham Galy (1977). Effect of different soil moisture levels on growth, yield and quality of Washington Navel orange. Agric. Res. Rev., Cairo, 55(3):47-57.

Abdel- Nasser, G. and S.M. EL- Shazly (2000).Irrigation management of Anna apple trees in relation to growth, yield, fruit quality, leaf constituents and plant water relations. Alex. J. Agric. Res. 45(1): 225-247.
Acevedo, E.; T.C. Hsiao and D.W. Henderson (1971). Immediate and subsequent growth of maize leaves to changes in water status. Plant Physiol. 48:631-636.

Ahmed, B.B.R. (1990). Physiological studies on drought resistance of Fig transplant. Ph. D thesis, Fac. of Agric. Hort. Dept., Ain Shams Univ. Cairo, Egypt.

Ahmed , F.F. and M.A.M.Abo-Shelbaya (1988). Effect of foliar sprays of urea and micronutrients on improving the productivity of Balady mandarin cultivar. Assuit J. of Agric. Sci. Vol. 19(3):103-114.

Albrigo, L.G. (1999). Effect of foliar application of urea or Nutriphite on flowering and yields of Valencia orange trees. Proc. of the Florida State Hort. Soc., No.112:1-4.

Ali, A.G. and C.J. Lovatt (1992). Winter application of foliar urea. Citrograph, 78:79.

A.O.A.C (1985) Official Methods of Analysis of the Association of Official Agricultural Chemists Published by the A.O.A.C, $14^{\text {th }}$ Ed. Washington.D.C

Bradford, k.J. and T.C. Hsiao (1982). Physiological responses to moderate water stress. P. 246-312. In : Lange, O.L., P.S. Nobel, C.B. Osmond and H.Ziegler (eds.) Physiological Ecology II. Water relations and carbon assimilation. Encyclopedia of plant physiology. N.S. Vol. $12 \mathrm{~B}$.

Bredell, G.S. and C.Y. Barnard (1977). Microjets for macro efficiency. Proc. int. Soc. Citric (Orlando) 1:87-92.

Castel, J.R. and Buj (1990). Response of Solustiana oranges to high frequency deficit irrigation. Irr. Sci., 11:121-127.

Cruse, R.R.;C.L.Wiegand and W.A.Swanson (1982). The effect of rainfall and irrigation mangement on citrus juice quality in Texas. J. Amer. Soc. Hort. Sci., 107:767-770.

Dariusz, S. (1986). The performance of trickle and flood irrigated young Ruby red grapefruit trees. International Horticultural Congress, Davis, USA, 11-20 Aug.

Döring, j. and p. Ludders (1981). Effect of a differing nitrogen nutrition on the growth, leaf carbohydrate content and net assimilation rate of Citrus madurensis. Mitteilungen Klosterneuburg, 31 (1):31-38 (Hort.Abst., 51(6):4983).

Dubois, M.; K.A. Gilles; J.K. Hamiltain; P.A. Rebers and F. Smith (1956). Colorimetric method for determination of sugars and related substances. Anal. Chem., 28 (3):350356.

EL-Boray, M.S.; F.G. Guirguis; M.A. Iraqi and A.EL-Hussani (1995). Effect of irrigation and nitrogen fertilization on vegetative growth, yield and fruit quality of Washington Navel orange trees. J. Agric. Sci. Mansoura Univ., 20 (6): 3075-3083.

EL-Tanany, M.M. and M.N.Abdel Messih (2009). Effect of foliar application with urea on flowering, fruiting and leaf nitrogen content of Valencia orange trees. J.Agric. Sci. Mansoura, Univ., 34 (8): 8915-8926.

Goell, A.; A. Golomb, D. Kalmar and A.Mantell (1981). Moisture stress-A potent factor for affecting vegetative growth and tree size in citrus. Proc. intl. Soc. Citricult., 2:503-506. 
Gonzalez- Altozano, p. and J.R.Castel (1999). Regulated deficit irrigation in Clementina de Nule's citrus trees. I. Yield and fruit quality effects. Hort. Sci. Biotechnol., 74:706-713.

Ganzolez-Altozano, P. and J.R. Castel (2000). Regulated deficit irrigation in Clementina de Nule's citrus trees. II. Vegetatie growth. J. Hort. Sci.Biotechnol., 75:389-392.

Ginestar, C. and J.R. Castel (1996). Response of young Celementine citrus to water stress during different phenological periods. Hort. Sci., 71:551-559.

Handa, S.; R.A. Bressan; A.K.Handa, N.C.Carpita and P.M. Hasawa (1983). Solute contributing to osmotic adjustment in cultured plant cell adapted to water stress. Plant Physiol., 73:834-843.

Hassan, M.W.A; H.E. Kahalifa and Ahlam A.EL-Sayed (2001). Effect of nitrogen and potassium levels on Washington Navel orange production under drip irrigation system at south Tahrir area. Egypt. Alex. Sci. Exch. 22(3)239-254.

Heller, J.; J.Shalhevel and A.Goell (1973). Response of citrus orchard to soil moisture and soil salinity, P. 409-419. In; A.Hodos, D. Swartz endruber, P.E.Rijtema, M.L. Fuchs, and B. Yaron (eds.) Ecological Studies, Vol.4 Springerverlage, Berlin.

Hilgeman, R.H. (1977). Response of citrus trees to water stress in Arizona. Proc. intl. Soc. Citricult., 1:70-74.

Hilgeman, R.H. and F.O.Sharp (1970). Response of Valencia orange trees to four soil-water schedules during 20 years. J. Amer. Soc. Hort. Sci. 95:739-745.

Johnson, G.R.; T.A.Nell; S.E.Risenbaum and J.A.Lauritis (1982). Influence of light intensity stress on fig benjamina L.J.Amer. Soc. Hort. Sci., 107(2):252-255.

Levy, Y.; H.Bielorai and J.Shalhevet (1978). Long-term effects of different irrigation regimes on grapefruit trees development and yield. J. Amer. Soc. Hort. Sci., 103:680683.

Levy, Y;J.Shalhevet and H.Bielorai (1979). Effect of irrigation regime and water salinity on grapefruit quality. J. Amer. Soc. Hort. Sci., 104:356-359.
Malik, C.P. and M.B. Singh (1980). Plant enzymology and histenzymology. A. Text Manual. Kalyani publishers., New Deilhi. India.

Mc Cutchan, H. and K.A Shackel (1992). Stem-water potential as a sensitive indicator of water stress in prune trees (prunus domestica L. cv. French). J.Amer. Soc. Hort. Sci. (4): 607-611.

Moran, R. and D. Porath (1980). Chlorophyll determination in intact tissue using N,N-dimethyl formamide. Plant Physiology., 65:478-479.

Robinson, S.P.; W.J.R. Grant and B.R. Loveys (1988). Stomatal limitation of photosynthesis in abscisic acidtreated and in water stressed leaves measures of elevates $\mathrm{CO}_{2}$. Austral. J.Physiol., 15(4):495-503.

Romero-Aranda, R. and J.P. Syvertsen (1996). The influence of foliar-applied urea nitrogen and saline solutions on net gas exchange of citrus leaves. J. Amer. Soc. Hort. Sci., 121 (3):501-506.

Romero, P; J.M.Navarro, J.Perez-perez; F.Garcia - Sanchez; A.Gomez-Gomez L.Porras, V.Martinez and P.Botia (2006). Deficit irrigation and rootstock: Their effects on water relation, vegetative development, yield, fruit quality and mineral nutrition of Clemenulues mandarin. Tree physiology., 26(12):1537-1548.

Saleem, B.A.; A.Malik, M.Maqubool; I.M. Din; M.Farooqu and I.A. Rajwana (2008). Early winter spray of low-biuret urea improves marketable yield and fruit quality of sweet orange. Pak. J.Bot., 40(4):1455-1465.

Snedecor, G.W. and W.Cochran (1982). Statistical Methods. $7^{\text {th }}$ Edition. Aiwa state Univ. Press. Amer. Aiwa. U.S.A pp. 507.

Swellem, A. (1986). Effect of irrigation on the vegetative growth, yield and fruit quality of Valencia orange trees. M.Sc. Thesis, Fac. of Agric., Zagazig Univ., Egypt.

Tomas, A. and E.Robert (1993). Fertilizer effects on early growth and yield of Hamlin orange trees. Hort. Sci., 28(2):111-114.

Wiegand, C.L. and W.A.Swanson (1982). Marrs, Valencia and Ruby red juice quality as affected by irrigation and rainfall. J. Rio Grande Valley Hortic. Soc., 35:109-120.

Young, R.H. and S.M. Garnsey (1977). Water uptake patterns in blighted citrus trees. J.Amer. Soc. Hort. Sci., 102:751756. 


\section{الملخص العربي}

\section{تأثير التصويم والرش الورقى باليوريا على إنتاجيه أشجار الليمون البلدى ب-النمو الحضرى ومحتوى الاوراق من الكلوروفيل وجزيئات الكربوهيدرات فى الأوراق وجودة الثمار في أشجار الليمون}

محمود عُمَّمَ الطنانى، مرفت صديق ثُمَّمَ سرور، إيناس عبد العزيز طايل

-بالنسبة لصفات الثمار الفيزيائية، أكدت النتائج بإنه في الموسم إينابل

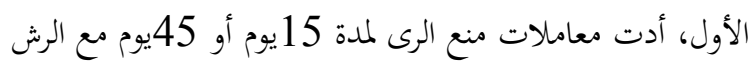

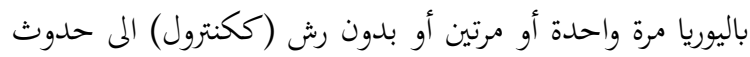

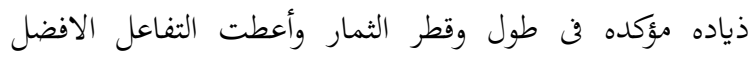

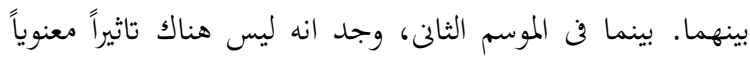
لفترات منع الرى او للرش الورقى باليوريا على طول الثمار

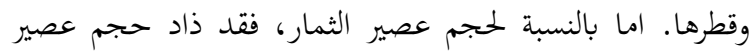

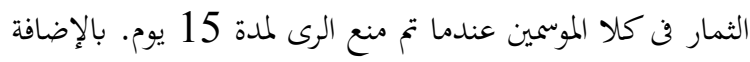

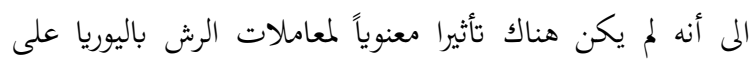
حجم عصير الثمار وخصوصاً فن السنة الاولى من الدراسة. وكانت افضل التفاعلات في حجم عصير الثمار هو ما بين منع الرى لمدة 15 يوم مع الرش باليوريا مرة واحدة.

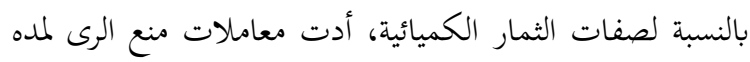

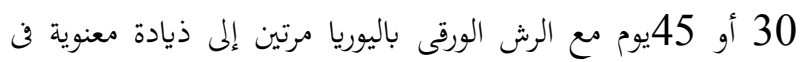

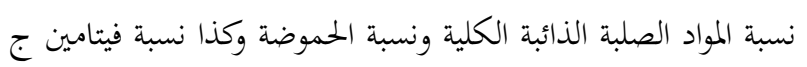
في عصير الثمار. واعطت أفضل التفاعلات. وعلى النقيض من ذلك،

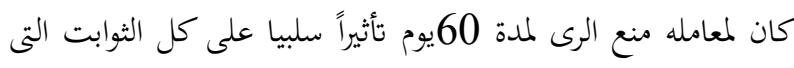
ذكرت من قبل وقللت من صفات جودة الثمار.
أجريست هـذه التجربـة خـلال مــوسمى نمــ 2005/ 2006و

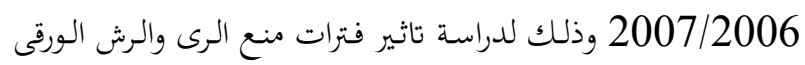

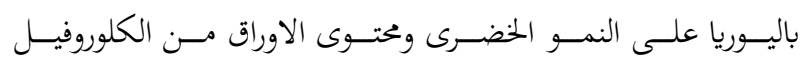

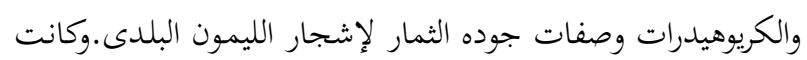

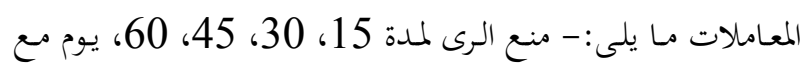

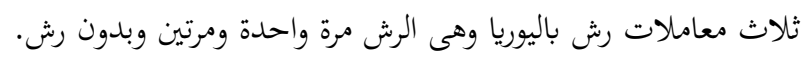
وقد أوضحت النتائج المتحصل عليها ما يلى: - كانت معامله منع الرى لمدة 30يوم مع معاملات الرش باليوريا مرة

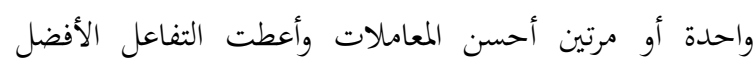
بينهما حيث أدت إلى ذيادة طول الافرع والمساحة الورقية.

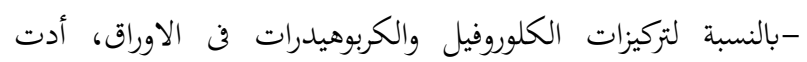

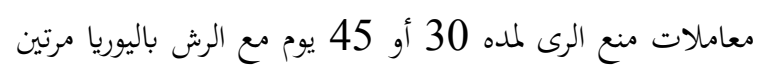

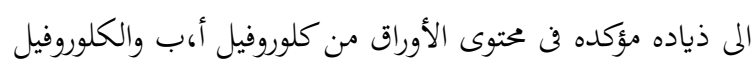

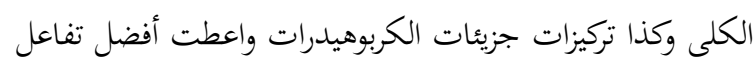
بينهما. فضلاً عن أنه كان التفاعل بين منع الرى لمدة 15 يورم

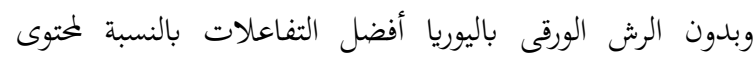

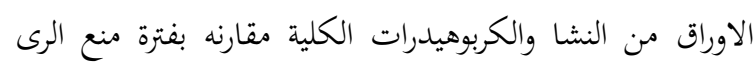
لمدة 60يوم مع الرش باليوريا مرتين وذلك في كلا موسمى الدراسة. 